\title{
PEMBUATAN BAHAN BAKU SPREADS KAYA KAROTEN DARI MINYAK SAWIT MERAH MELALUI INTERESTERIFIKASI ENZIMATIK MENGGUNAKAN REAKTOR BATCH
}

\author{
[Preparation of Red Palm Oil Based-Spreads Stock Rich in Carotene \\ Through Enzymatic Interesterification in Batch-type Reactor]
}

\author{
Sugiyono ${ }^{1,2)^{*}}$, Mario Wibowo1), Soenar Soekopitojo2) dan Nur Wulandari 1,2) \\ 1) Departemen IImu dan Teknologi Pangan, Fakultas Teknologi Pertanian, Institut Pertanian Bogor, Bogor \\ 2) Southeast Asian Food and Agricultural Science and Technology (SEAFAST) Center, Institut Pertanian Bogor, Bogor
}

Diterima 08 Oktober 2010 / Disetujui 30 April 2012

\begin{abstract}
Enzymatic interesterification of red palm oil (a mixture of red palm olein/RPO and red palm stearin/RPS in 1:1 weight ratio) and coconut oil (CNO) blends of varying proportions using a non-specific immobilized Candida antartica lipase (Novozyme 435) was studied for the preparation of spread stock. The interesterification reaction was held in a batch-type reactor. Two substrate blends were chosen for the production of spread stock i.e. 77.5:22,5 and 82.5:17.5 (RPO/RPS:CNO, by weight) through enzymatic interesterification in three different reaction times (2, 4, and 6 hours). The interesterification reactions were conducted at $60^{\circ} \mathrm{C}, 200 \mathrm{rpm}$ agitation speed and $10 \%$ of Novozyme 435 . The interesterified products were evaluated for their physical characteristics (slip melting point or SMP and solid fat content or SFC) and chemical characteristics (carotene retention, moisture content, and free fatty acid/FFA content). All of the interesterified products had lower SFC and SMP as compared to the initial blends. The SMP and SFC increased in longer reaction times. The SMP ranged from $30.8^{\circ} \mathrm{C}$ to $34.9^{\circ} \mathrm{C}$. The carotene retention ranged from $74.80 \%$ to $81.08 \%$, while the moisture content and FFA content increased in longer reaction times. The interesterified products had desirable physical properties for possible use as a spread stock rich in carotene.
\end{abstract}

Keywords: batch-type reactor, enzymatic interesterification, red palm oil, solid fat content, spread stock

\begin{abstract}
ABSTRAK
Pada penelitian ini dilakukan interesterifikasi enzimatik minyak sawit merah (campuran olein minyak sawit merah (RPO) dan stearin minyak sawit merah (RPS) dengan perbandingan berat 1:1) dan minyak kelapa dalam beberapa perbandingan menggunakan enzim lipase non-spesifik terimobilisasi dari Candida antartica (Novopzyme 435) untuk membuat bahan baku spreads. Reaksi interesterifikasi dilakukan pada reaktor batch. Campuran RPO/RPS dan minyak kelapa dengan perbandingan berat 77,5:22,5 dan 82,5:17,5 digunakan sebagai bahan baku reaksi interesterifikasi pada tiga lama waktu yang berbeda yaitu 2, 4, dan 6 jam. Reaksi interesterfikasi dilakukan pada suhu $60^{\circ} \mathrm{C}$, kecepatan agitasi 200 rpm dan konsentrasi enzim terimobilisasi 10\%. Produk interesterifikasi dianalisa karateristik fisiknya (titik leleh atau SMP dan kadar lemak padat atau SFC) dan karakteristik kimianya (retensi karoten, kadar air, dan kadar asam lemak bebas). Semua produk hasil interesterifikasi memiliki SMP dan SFC yang lebih rendah dari campuran bahan bakunya. Nilai SMP dan SFC meningkat dengan bertambahnya lama reaksi. Nilai SMP berkisar $30,8^{\circ} \mathrm{C}-34,9^{\circ} \mathrm{C}$. Retensi karoten berkisar $74,80 \%-81,08 \%$. Kadar air dan kadar asam lemak bebas meningkat dengan bertambahnya lama reaksi. Produk hasi interesterfikasi memiliki sifat fisik yang dikehendaki untuk penggunaan sebagai bahan baku spreads kaya karoten.
\end{abstract}

Kata kunci: interesterifikasi enzimatik, reaktor batch, minyak sawit merah, kadar lemak padat, bahan baku spreads

\section{PENDAHULUAN}

Indonesia merupakan negara penghasil minyak sawit terbesar di dunia. Produksi minyak sawit Indonesia meningkat setiap tahunnya. Pada tahun 2008, produksi minyak sawit Indonesia sebanyak 19 juta ton (Pusat Penelitian Kelapa Sawit, 2010). Pada tahun 2010 produksi minyak sawit Indonesia mencapai 19,84 juta ton dengan luas areal perkebunan sawit 7,82 juta hektar (Ditjenbun, 2011).

Menurut Rossi et al. (2001) minyak sawit kasar (CPO) mengandung karotenoid 500-700 ppm, terutama dalam bentuk alfa dan beta karoten. Karotenoid bermanfaat bagi kesehatan

*Korespondensi Penulis :

Email : sugiyono@ipb.ac.id; Telp.+62-251-8626725 sebagai pro-vitamin A. Dalam pengolahan minyak sawit menjadi berbagai produk hilir, karotenoid seringkali sengaja dihilangkan. Salah satu upaya mempertahankan kandungan karotenoid pada minyak sawit adalah pembuatan minyak sawit merah. Pada penelitian ini digunakan minyak sawit merah sebagai bahan dasar dalam penyiapan bahan baku spreads.

Spreads merupakan produk berbasis lemak, berbentuk padat, plastis dan mempunyai tekstur yang lunak sehingga dapat dengan mudah dioleskan (spreadable). Salah satu produk spreads yang populer adalah margarin. Minyak sawit merah memiliki sifat fisik yang cocok sebagai bahan baku produk spreads yaitu memiliki stabilitas terhadap oksidasi dan termal yang tinggi serta plastis pada suhu ruang (Lida et al., 2002).

Untuk memperbaiki kandungan lemak padat dalam bahan baku spreads berbasis minyak sawit merah, maka ditambahkan 
Versi Online:

http://journal.ipb.ac.id/index.php/jtip

DOI: 10.6066/jtip.2012.23.2.117

Hasil Penelitian

J. Teknol. dan Industri Pangan, Vol. XXIII No. 2 Th. 2012

minyak kelapa. Bahan baku spreads dalam penelitian in disiapkan melalui proses interesterifikasi enzimatik campuran minyak sawit merah dan minyak kelapa. Interesterifikasi enzimatik minyak sawit merah dengan minyak kelapa diharapkan dapat menghasilkan bahan baku spreads yang memiliki sifat plastis sehingga mempunyai kemampuan untuk dioleskan (spreadable). Tujuan penelitian ini adalah mempelajari pengaruh reaksi interesterifikasi enzimatik menggunakan reaktor batch terhadap karakteristik bahan baku spreads berbasis minyak sawit merah, yang meliputi total karoten, slip melting point (SMP), solid fat content (SFC), kadar air, dan kadar asam lemak bebas.

\section{BAHAN DAN METODE}

\section{Bahan}

Bahan yang digunakan pada penelitian adalah minyak sawit merah yang telah dinetralkan (neutralized deodorized red palm oil atau NDRPO) yang disiapkan menurut Hasrini et al. (2009), minyak kelapa (CNO) merk Barco, Lipozyme TL IM (lipase Thermomyces lanuginosa terimobilisasi spesifik sn-1,3) dan Novozyme 435 (lipase Candida antartica terimobilisasi nonspesifik) yang merupakan produk Novo Nordisk Bioindustrial Ltd., Denmark. Bahan-bahan untuk analisis kimia adalah heksana p.a., etanol $95 \%$ netral, indikator fenoftalein, $\mathrm{NaOH}$ $0,25 \mathrm{~N}$, gas $\mathrm{N}_{2}$, dan air destilata.

\section{Karakterisasi bahan baku}

Tahap ini bertujuan untuk mengetahui kondisi awal bahan baku sehingga dapat diketahui peluangnya untuk proses interesterifikasi enzimatik. Sebelum karakterisasi, dilakukan terlebih dahulu proses fraksinasi dan pencampuran. Proses fraksinasi bertujuan untuk mendapatkan RPO dan RPS. Proses fraksinasi pada penelitian ini menggunakan metode Aini et al. (2005) yang dimodifikasi Hasrini et al. (2009).

Proses fraksinasi dilakukan sebagai berikut: NDRPO dipanaskan pada suhu $60^{\circ} \mathrm{C}$ selama 30 menit, lalu NDRPO tersebut dipindahkan ke dalam tabung sentrifus $50 \mathrm{ml}$ dan didiamkan semalam ( \pm 16 jam). Pemisahan RPO dan RPS dilakukan dengan sentrifus (Eppendorf 5810 R, Hamburg), pada kecepatan 2500 rpm selama 25 menit. Setelah proses fraksinasi, dilakukan proses pencampuran RPO, RPS, dan CNO (coconut oil). Proses pencampuran dilakukan dengan cara mencampurkan RPO/RPS (1:1) dan CNO dengan perbandingan $75: 25,77,5: 22,5$, dan 82,5:17,5 (b/b). Karakteristik yang dianalisa pada tahap ini adalah total karoten slip melting point (SMP), solid fat content (SFC), kadar air, serta kadar asam lemak bebas (ALB).

\section{Pemilihan campuran bahan baku}

Tahap ini bertujuan untuk memilih dua campuran terbaik. Pemilihan campuran bahan baku dilakukan terhadap tiga campuran hasil penelitian Hasrini et al. (2009) yaitu campuran (RPO/RPS)/CNO dengan rasio 75:25, 77,5:22,5, dan 82,5:17,5 (b/b). Rasio RPO/RPS yang digunakan adalah 1:1 (b/b). Ketiga campuran tersebut digunakan dalam proses interesterifikasi enzimatik.

Prosedur interesterifikasi enzimatik dilakukan mengikuti Zhang et al. (2001) yang dimodifikasi Hasrini et al. (2009). RPO/RPS ditambahkan CNO masing-masing dengan rasio sesuai perlakuan sebanyak $10 \mathrm{~g}$, lalu dimasukkan ke dalam erlenmeyer $25 \mathrm{ml}$ dan diagitasi dengan inkubator goyang (New Brunswick Scientific, New Jersey) pada kecepatan 200 rpm dan suhu $60^{\circ} \mathrm{C}$. Setelah mencapai suhu $60^{\circ} \mathrm{C}$ dan sampel telah meleleh sempurna, kemudian dimasukkan Lipozyme TL IM terimobilisasi sebanyak 10\% (b/b) dan diagitasi kembali selama 4 jam. Reaksi interesterifikasi dilakukan pada suhu $60^{\circ} \mathrm{C}$ sesuai dengan yang dilakukan oleh Xu et al. (2002), Kim et al. (2008), dan Chae et al. (2011), meskipun Lipozyme TL IM juga dapat digunakan pada suhu $70^{\circ} \mathrm{C}$ (Osório et al., 2006; Hernandez et al., 2007). Hasil interesterifikasi diangkat dan Lipozyme TL IM disaring. Sampel kemudian disimpan dalam botol kaca gelap, dihembus $\mathrm{N}_{2}$, dan disimpan dalam refrigerator (Sanyo Medicool, Sanyo Electric, Osaka). Analisis yang dilakukan meliputi total karoten, SMP dan SFC terhadap hasil interesterifikasi enzimatik dari tiga campuran yang telah ditentukan.

\section{Interesterifikasi enzimatik dengan reaktor batch}

Tahap ini bertujuan untuk menghasilkan bahan baku spreads melalui proses interesterifikasi enzimatik menggunakan reaktor batch. Enzim yang digunakan pada tahap ini adalah Novozyme 435. Selain itu, tahap ini juga bertujuan untuk mendapatkan karakteristik bahan baku spreads yang diproduksi dalam reaktor batch. Penelitian yang dilakukan adalah penyiapan bahan baku spreads menggunakan reaktor batch dengan perlakuan perbedaan lama reaksi yaitu 2, 4, dan 6 jam.

Produksi bahan baku spreads melalui prosedur sebagai berikut: RPO/RPS ditambahkan CNO masing-masing dengan rasio sesuai perlakuan sebanyak $50 \mathrm{~g}$ kemudian dimasukkan ke dalam reaktor batch (rancangan sendiri, kapasitas kerja $50 \mathrm{~g}$, Gambar 1), dan diagitasi dengan agitator pada kecepatan 200 rpm dan suhu $60^{\circ} \mathrm{C}$. Setelah mencapai suhu $60^{\circ} \mathrm{C}$ dan sampel telah meleleh sempurna, dimasukkan Novozyme 435 terimobilisasi sebanyak 10\% (b/b) dan diagitasi kembali selama 2 , 4, dan 6 jam. Hasil interesterifikasi tersebut diambil dan Novozyme 435 disaring. Sampel kemudian disimpan dalam botol kaca gelap, dihembus $\mathrm{N}_{2}$, dan disimpan dalam refrigerator. Analisis yang dilakukan terhadap hasil interesterifikasi enzimatik meliputi total karoten, SMP, SFC, kadar air, dan kadar ALB.

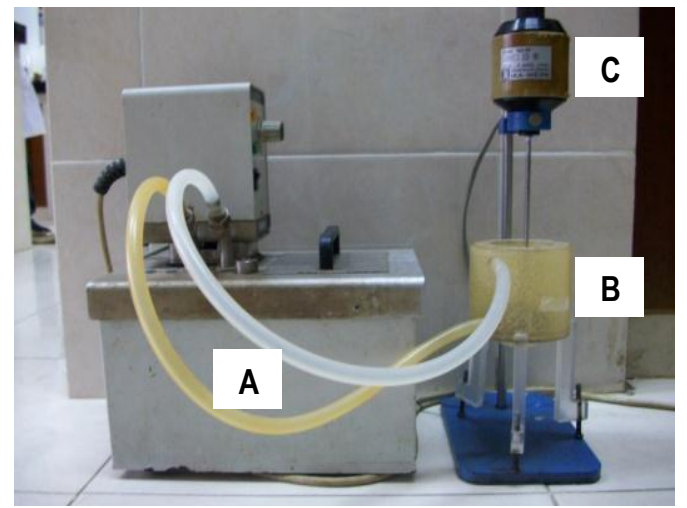


Versi Online:

http://journal.ipb.ac.id/index.php/jtip

DOI: 10.6066/itip.2012.23.2.117

Gambar 1. Reaktor batch yang digunakan dalam penelitian: (A) water

Analisis bath, (B) reaktor batch, dan (C) agitator

Analisis yang dilakukan terhadap sampel adalah total karoten (PORIM p2.6, 1995) menggunakan spektrofotometer (Spectronic 20D+, Thermo Fisher Scientific, Waltham), SMP (AOCS Official Method Cc 3-25, 1990), SFC (IUPAC 2.150 ex 2.323, 1987) menggunakan Bruker Minispec PC 100 Nuclear Magnetic Resonance Analyzer (Bruker Optics, Ettlingen), kadar air (AOAC, 1995) menggunakan oven (Memmert, Nurnberg) dan timbangan analitik (Precisa XT 220X, Precisa Gravimetrics, Dietikon), serta kadar ALB (AOCS Official Method Ca 5a-40 1990).

Data yang diperoleh diuji ragam (analysis of variance) untuk melihat adanya perbedaan nyata dalam data. Jika dalam data terdapat perbedaan nyata, maka dilakukan uji lanjut Duncan untuk melihat data yang berbeda nyata (Lea et al., 1997). Data disajikan dalam rata-rata \pm standar deviasi.

\section{HASIL DAN PEMBAHASAN}

\section{Karakteristik bahan baku}

Karakteristik yang dianalisa dari bahan baku minyak sawit merah adalah total karoten, SMP, SFC, kadar air, dan kadar asam lemak bebas. Analisis terhadap bahan baku dilakukan untuk mengetahui kondisi awal minyak sawit merah dan campuran bahan baku sehingga dapat diketahui peluangnya untuk proses interesterifikasi enzimatik.

Hasil analisis total karoten bahan baku disajikan pada Tabel 1. Gee (2007) menyebutkan bahwa kandungan karotenoid dalam minyak sawit kasar (CPO) berkisar 500-700 ppm. RPO memiliki kandungan karoten yang lebih tinggi dibanding RPO/RPS. Fraksi stearin sawit mengandung karoten yang lebih sedikit dibandingkan dengan fraksi olein. Stearin sawit lebih banyak mengandung monoasilgliserol, sterol, dan fosfolipid (Gee, 2007). Hal ini yang menyebabkan RPO mengandung karoten yang lebih tinggi daripada RPO/RPS.

Tabel 1. Total karoten bahan baku

\begin{tabular}{cc}
\hline Sampel & Total Karoten $(\mathrm{ppm}), \mathrm{n}=4$ \\
\hline NDRPO & $376,47 \pm 3,65$ \\
RPO & $351,36 \pm 12,07$ \\
RPO/RPS (1:1) & $343,27 \pm 7,89$ \\
M75 & $262,42 \pm 6,80$ \\
M77 & $265,01 \pm 12,65$ \\
M82 & $269,02 \pm 8,73$ \\
\hline
\end{tabular}

Keterangan: NDRPO $=$ neutralized deodorized red palm oil; RPO $=$ red palm olein; RPS = red palm stearin, M75= Rasio (RPO/RPS):CNO sebesar 75:25 (b/b); M77= Rasio (RPO/RPS):CNO sebesar 77,5:22,5 (b/b); M82= Rasio (RPO/RPS): CNO sebesar 82,5:17,5 (b/b)

Kandungan karoten dalam NDRPO lebih tinggi dibandingkan dengan RPO dan RPO/RPS. Hal ini diduga karena adanya pemanasan sebelum tahap fraksinasi yang menyebabkan kerusakan karoten. RPO/RPS banyak mengandung karoten, sedangkan pada CNO tidak terdapat karoten. Menurut Gee
(2007), kandungan karotenoid, diasilgliserol, tokoferol, dan tokotrienol banyak terkonsentrasi pada fraksi olein sawit. Oleh karena itu semakin banyak RPO/RPS maka kandungan karotennya juga semakin tinggi.

Karakteristik leleh dari minyak sawit dapat terlihat dari nilai SMP. SMP didefinisikan sebagai suhu saat lemak atau minyak memiliki padatan lemak sebesar 5\% (Lida et al., 1998). SMP dari lemak atau minyak berubah dengan adanya perubahan panjang asam lemak, rasio ketidakjenuhan, kandungan asam lemak trans dan posisi asam lemak pada struktur triasilgliserol (Karabulut et al., 2004). Nilai SMP meningkat secara berurutan pada sampel M75, M77, dan M82 (Tabel 2). Hal ini diduga disebabkan oleh adanya peningkatan konsentrasi RPS yang memiliki titik leleh lebih tinggi daripada RPO dan CNO.

Tabel 2. Nilai solid fat content (SFC) dan slip melting point (SMP) bahan baku

\begin{tabular}{|c|c|c|c|c|c|c|c|}
\hline \multirow{2}{*}{$\begin{array}{l}\text { Sam- } \\
\text { pel }\end{array}$} & \multicolumn{6}{|c|}{$\operatorname{SFC}(\%), n=4$} & \multirow{2}{*}{$\begin{array}{l}\text { SMP } \\
\left({ }^{\circ} \mathrm{C}\right), \\
\mathrm{n}=4\end{array}$} \\
\hline & $10^{\circ} \mathrm{C}$ & $20^{\circ} \mathrm{C}$ & $25^{\circ} \mathrm{C}$ & $30^{\circ} \mathrm{C}$ & $35^{\circ} \mathrm{C}$ & $40^{\circ} \mathrm{C}$ & \\
\hline $\begin{array}{l}\text { NDR } \\
\text { PO }\end{array}$ & 40,26 & 18,92 & 8,96 & 7,71 & 5,96 & 3,28 & - \\
\hline RPO & 32,93 & 10,03 & 4,90 & 1,47 & 1,33 & 1,17 & - \\
\hline RPS & 52,26 & 34,96 & 25,29 & 21,40 & 17,80 & 13,22 & . \\
\hline $\begin{array}{l}\text { RPO/ } \\
\text { RPS }\end{array}$ & 47,38 & 26,58 & 20,78 & 11,57 & 9,18 & 6,04 & - \\
\hline CNO & 69,50 & 29,84 & 7,36 & 2,26 & 1,24 & 1,04 & - \\
\hline M75 & 37,86 & 14,86 & 14,31 & 7,48 & 6,40 & 3,52 & $\begin{array}{l}34,1 \\
\pm 0,9\end{array}$ \\
\hline M77 & 41,41 & 16,53 & 12,65 & 9,88 & 7,50 & 4,92 & $\begin{array}{l}35,6 \\
\pm 0,5\end{array}$ \\
\hline M82 & 42,99 & 17,23 & 16,49 & 11,76 & 8,31 & 5,15 & $\begin{array}{r}36,5 \\
\pm 0,4 \\
\end{array}$ \\
\hline
\end{tabular}

Keterangan: M75= Rasio (RPO/RPS):CNO sebesar 75:25 (b/b); M77= Rasio (RPO/RPS):CNO sebesar 77,5:22,5 (b/b); M82= Rasio (RPO/RPS):CNO sebesar 82,5:17,5 b/b)

SFC adalah jumlah kristal lemak yang terkandung dalam campuran lemak/minyak. Nilai SFC diukur pada suhu $10-40^{\circ} \mathrm{C}$. Tabel 2 menunjukkan nilai SFC dari sampel bahan baku. Nilai SFC meningkat dengan adanya peningkatan komposisi RPO/RPS. Adhikari et al. (2010) menyatakan bahwa penambahan stearin sawit dapat meningkatkan SFC campuran lemak atau minyak.

Kadar air dan kadar ALB merupakan karakteristik yang penting dalam reaksi interesterifikasi enzimatik. Kadar air dapat memengaruhi kadar ALB dalam produk minyak sawit. Minyak yang ideal untuk interesterifikasi enzimatik mengandung kadar air dan kadar ALB kurang dari 0,1\% (Cowan, 2009). Berdasarkan Tabel 3, kadar air bahan baku sudah memenuhi syarat, sedangkan kadar ALB sedikit melewati batas ideal untuk reaksi interesterifikasi enzimatik. Walaupun demikian, menurut PORIM test method (1995) batas penerimaan kadar ALB untuk minyak sawit dan produk turunannya adalah $0,5-1 \%$.

Menurut Zhang et al. (2000), tahap pertama dari interesterifikasi yang dikatalisis oleh lipase adalah hidrolisis yang menghasilkan ALB dan diasilgliserol; sedangkan tahap kedua adalah esterifikasi antara diasilgliserol dan ALB sehingga 
Versi Online:

http://journal.ipb.ac.id/index.php/jtip

DOI: 10.6066/itip.2012.23.2.117

Hasil Penelitian

J. Teknol. dan Industri Pangan, Vol. XXIII No. 2 Th. 2012

membentuk triasilgliserol yang baru. Reaksi interesterifikasi ini membutuhkan air. Akan tetapi, jika terlalu banyak air, reaksi cenderung mengarah ke hidrolisis yang menghasilkan ALB dan diasilgliserol sebagai produk akhir.

Tabel 3. Kadar air dan kadar asam lemak bebas (ALB) bahan baku

\begin{tabular}{lcc}
\multicolumn{1}{c}{ Sampel } & Kadar Air $(\%), \mathrm{n}=4$ & Kadar ALB $(\%), \mathrm{n}=4$ \\
\hline NDRPO & $0,065 \pm 0,004$ & $1,33 \pm 0,01$ \\
RPO & $0,093 \pm 0,001$ & $1,29 \pm 0,00$ \\
RPO/RPS & $0,105 \pm 0,003$ & $1,40 \pm 0,05$ \\
CNO & $0,029 \pm 0,002$ & $0,30 \pm 0,00$ \\
M75 & $0,083 \pm 0,000$ & $1,00 \pm 0,01$ \\
M77 & $0,086 \pm 0,000$ & $1,15 \pm 0,04$ \\
M82 & $0,093 \pm 0,002$ & $1,26 \pm 0,03$ \\
\hline
\end{tabular}

Keterangan: NDRPO $=$ neutralized deodorized red palm oil; RPO $=$ red palm olein; RPS = red palm stearin; $\mathrm{CNO}=$ coconut oil; M75= Rasio (RPO/RPS): CNO sebesar 75:25 (b/b); M77= Rasio (RPO/RPS):CNO sebesar 77,5:22,5 (b/b); M82= Rasio (RPO/RPS): CNO sebesar 82,5:17,5 (b/b)

\section{Campuran bahan baku}

Campuran bahan baku yang digunakan dalam penelitian ini adalah campuran antara RPO/RPS dan CNO dengan rasio $75: 25,77,5: 22,5$, dan 82,5:17,2 (b/b). Campuran ini berdasarkan hasil penelitian Hasrini et al. (2009). Ketiga campuran ini diinteresterifikasi menggunakan Lypozyme TL IM dalam erlenmeyer menggunakan inkubator goyang. Hasil interesterifikasi dianalisa total karoten, nilai SMP, dan profil SFC untuk mengetahui campuran mana yang karakternya paling mendekati karakter margarin target (Fattahi-far et al., 2006) dan yang memiliki kandungan karoten tinggi.

Hasil analisis total karoten pada sampel sebelum dan sesudah interesterifikasi enzimatik disajikan pada Tabel 4. Hasi uji ragam memperlihatkan bahwa total karoten antar sampe berbeda nyata $(p<0,05)$. Uji lanjut Duncan menunjukkan bahwa total karoten sampel sebelum dan sesudah interesterifikasi enzimatik berbeda nyata. Total karoten pada sampel M75, M77, dan M82 tidak berbeda nyata. Hal ini diduga karena komposisi RPO/RPS dalam M75, M77, dan M82 tidak berbeda jauh, sehingga kandungan karoten di dalamnya juga tidak banyak berbeda. Pada Tabel 4 terlihat bahwa total karoten sesudah interesterifikasi enzimatik lebih rendah daripada sebelum interesterifikasi enzimatik. Penurunan karoten yang terjadi relatif rendah (retensi karoten tinggi) karena interesterifikasi dilakukan pada suhu yang relatif rendah yaitu $60^{\circ} \mathrm{C}$. Karoten banyak terdapat pada RPO/RPS. Oleh karena itu semakin banyak komposisi RPO/RPS maka total karoten dalam sampel juga semakin tinggi. Sampel M77 dan M82 adalah dua sampel dengan kandungan karoten terbanyak.

Retensi karoten berkisar antara 79,98-84,38\%. Retensi karoten dihitung berdasarkan perbandingan total karoten yang tersisa sesudah interesterifikasi enzimatik terhadap jumlah karoten awal. Data pada Tabel 4 menunjukkan bahwa semakin tinggi kandungan karoten awal, maka retensi karoten juga semakin besar. Budiyanto et al. (2008) menyatakan bahwa perubahan kandungan $\beta$-karoten pada minyak sawit merah sangat dipengaruhi oleh konsentrasi $\beta$-karoten awal pada minyak sawit merah, suhu pemanasan, dan lama pemanasan minyak sawit merah.
Hasil uji ragam menunjukkan bahwa SMP antar sampel berbeda nyata $(p<0,05)$. Hasil uji Duncan menunjukkan bahwa SMP sampel sebelum dan sesudah interesterifikasi enzimatik berbeda nyata. SMP sampel M75 sesudah interesterifikasi enzimatik tidak berbeda nyata dengan M77, sampel M77 tidak berbeda nyata dengan M82. Interesterifikasi enzimatik dapat mengubah nilai SMP. SMP sampel sebelum dan sesudah interesterifikasi enzimatik dibandingkan dengan margarin komersial dan margarin komersial menurut Fattahi-far et al. (2006) diperlihatkan pada Tabel 5

Tabel 4. Kadar total karoten sebelum dan sesudah interesterifikasi enzimatik (IE)

\begin{tabular}{lccc}
\hline \multirow{2}{*}{ Sampel } & \multicolumn{2}{c}{ Total Karoten $(\mathrm{ppm}), \mathrm{n}=4$} & Retensi Karoten (\%), \\
& Sebelum IE & Sesudah IE & $\mathrm{n}=4$ \\
\hline M75 & $262,42 \pm 6,80^{\mathrm{b}}$ & $209,88 \pm 0,28^{\mathrm{a}}$ & 79,98 \\
M77 & $265,01 \pm 12,65^{\mathrm{b}}$ & $212,92 \pm 4,84^{\mathrm{a}}$ & 80,34 \\
M82 & $269,02 \pm 8,73^{\mathrm{b}}$ & $227,00 \pm 0,83^{\mathrm{a}}$ & 84,38 \\
\hline
\end{tabular}

Keterangan: Angka yang diikuti huruf yang sama tidak berbeda nyata dengan uji ragam dan uji lanjut Duncan pada taraf 5\%. M75= Rasio (RPO/RPS): CNO sebesar 75:25 (b/b); M77= Rasio (RPO/RPS):CNO sebesar 77,5:22,5 (b/b); M82= Rasio (RPO/RPS): CNO sebesar 82,5:17,5 (b/b)

Tabel 5. Nilai slip melting point (SMP) sebelum dan sesudah interesterifikasi enzimatik (IE) dibandingkan dengan SMP margarin komersial dan margarin target (Fattahi-far et al., 2006)

\begin{tabular}{lcc}
\hline \multirow{2}{*}{ Sampel } & \multicolumn{2}{c}{$\operatorname{SMP}\left({ }^{\circ} \mathrm{C}\right), \mathrm{n}=4$} \\
\cline { 2 - 3 } & Sebelum IE & Sesudah IE \\
\hline M75 & $34,1 \pm 0,9^{\text {cd }}$ & $30,1 \pm 0,9^{\mathrm{a}}$ \\
M77 & $35,6 \pm 0,5^{\mathrm{de}}$ & $31,4 \pm 0,5^{\mathrm{ab}}$ \\
M82 & $36,5 \pm 0,4^{\mathrm{e}}$ & $32,5 \pm 0,7^{\mathrm{bc}}$ \\
Margarin komersial A & & $35,6 \pm 0,2$ \\
Margarin komersial B & & $37,2 \pm 0,0$ \\
Margarin target & & $33,5 \pm 0,5$ \\
(Fattahi-far et al., 2006) & & \\
\hline
\end{tabular}

Keterangan: Angka yang diikuti huruf yang sama tidak berbeda nyata dengan uji ragam dan uji lanjut Duncan pada taraf 5\%. M75= Rasio (RPO/RPS):CNO sebesar 75:25 (b/b); M77= Rasio (RPO/RPS):CNO sebesar 77,5:22,5 (b/b); M82= Rasio (RPO/RPS): CNO sebesar 82,5:17,5 (b/b)

Sampel sesudah interesterifikasi enzimatik memiliki SMP yang lebih rendah $\left(30,1-32,5^{\circ} \mathrm{C}\right)$ dibandingkan sampel sebelum interesterifikasi enzimatik $\left(34,1-36,5^{\circ} \mathrm{C}\right)$ pada semua campuran. Penurunan SMP akibat proses interesterifikasi juga dilaporkan oleh Goli et al. (2008), Ribeiro et al. (2009), Soares et al. (2009), Sellami et al. (2012), Soares et al. (2012), Khatoon et al. (2012), dan Lee et al. (2008). Penurunan SMP ini disebabkan karena perubahan profil triasilgliserol akibat interesterifikasi (Ribeiro et al., 2009; Liu et al., 2010). Dalam hal ini diduga triasilgliserol yang terbentuk memiliki titik leleh yang lebih rendah sehingga SMP sesudah interesterifikasi enzimatik menjadi lebih rendah. Setiap sampel sesudah interesterifikasi enzimatik memiliki SMP di bawah suhu tubuh, yang artinya tidak menimbulkan tekstur seperti lilin (waxy) ketika dikonsumsi. SMP sampel M77 dan M82 adalah yang paling mendekati SMP margarin komersial dan margarin target. Oleh karena itu campuran M77 dan M82 (keduanya memiliki SMP yang tidak 
Versi Online:

http://journal.ipb.ac.id/index.php/jtip

DOI: 10.6066/itip.2012.23.2.117

Hasil Penelitian

J. Teknol. dan Industri Pangan, Vol. XXIII No. 2 Th. 2012

berbeda nyata) digunakan sebagai bahan baku dalam penelitian tahap ketiga, yaitu interesterifikasi enzimatik menggunakan reaktor batch.

SFC memengaruhi karakteristik fisik dari produk spreads, seperti kekerasan, mouthfeel, dan spreadability. Gambar 2-4 menunjukkan profil SFC sampel sebelum dan sesudah interesterifikasi enzimatik yang dibandingkan dengan profil SFC margarin komersial $A$, margarin komersial $B$, dan margarin target (Fattahi-far et al., 2006).

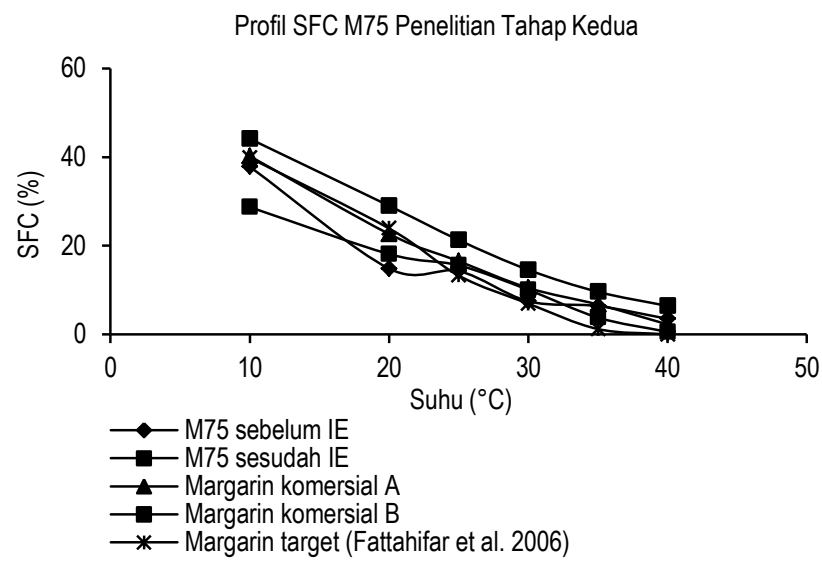

Gambar 2. Profil SFC dari campuran M75 $(n=4)$ sebelum dan sesudah interesterifikasi enzimatik (IE)

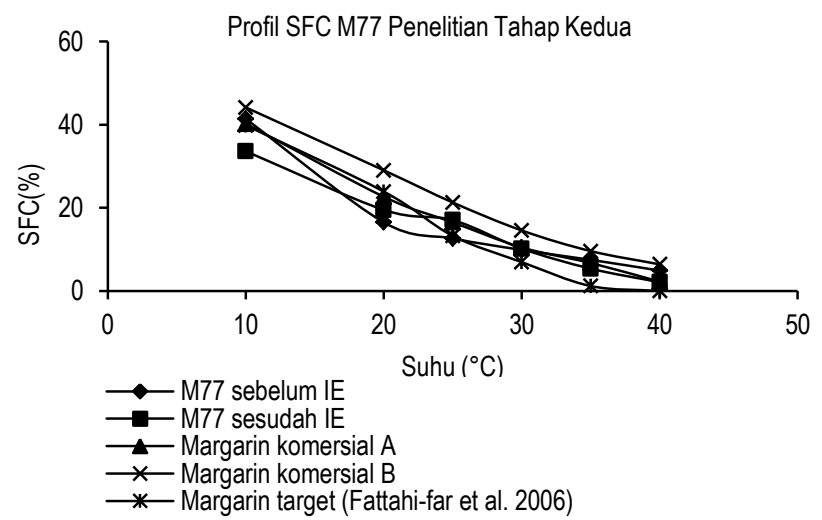

Gambar 3. Profil SFC dari campuran M77 $(n=4)$ sebelum dan sesudah interesterifikasi enzimatik (IE)

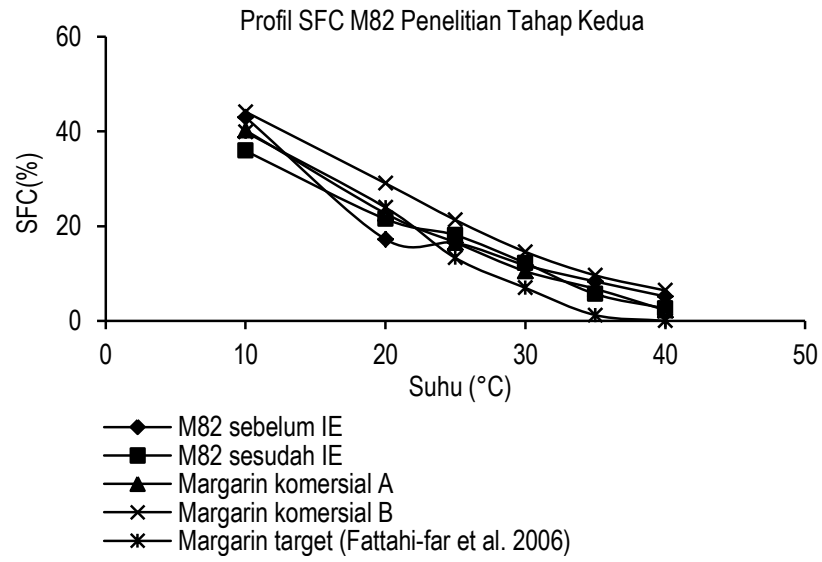

Gambar 4. Profil SFC dari campuran M82 (n = 4) sebelum dan sesudah interesterifikasi enzimatik (IE)

SFC pada suhu $10^{\circ} \mathrm{C}$ lebih tinggi dibandingkan dengan SFC pada suhu pengukuran lainnya. Hal ini menunjukkan bahwa SFC berbanding terbalik dengan suhu. Semakin tinggi suhu, maka SFC semakin rendah (Maulina, 2004). SFC meningkat dengan meningkatnya jumlah RPO/RPS. RPS mengandung banyak trisaturated triacylglycerol bertitik leleh tinggi, sehingga semakin tinggi komposisi RPS maka SFC juga semakin tinggi. Hasil interesterifikasi memiliki profil SFC yang mirip dengan margarin target dan lebih rendah dibandingkan dengan margarin komersial.

\section{Interesterifikasi enzimatik dengan reaktor batch}

Campuran yang digunakan pada penelitian tahap ketiga adalah M77 dan M82. Campuran M77 dan M82 dipilih dengan pertimbangan nilai SMP-nya paling mendekati SMP margarin komersial dan retensi karotennya tinggi. Hasil interesterifikasi pada penelitian tahap ketiga dianalisa total karoten, SMP, SFC, kadar air, dan kadar ALB. Hasil uji ragam menunjukkan bahwa total karoten antar sampel berbeda nyata $(p<0,05)$. Uji lanjut Duncan menunjukkan bahwa total karoten sampel sebelum dan sesudah interesterifikasi enzimatik berbeda nyata. Total karoten antar sampel sesudah interesterifikasi enzimatik tidak berbeda nyata, kecuali antara sampel M822 dengan sampel M774 dan M776. Total karoten sampel M774 dan M776 tidak berbeda nyata. Menurut Choo (1993), karoten bersifat labil terhadap panas dan jumlahnya menurun drastis pada suhu sekitar 180 $220^{\circ} \mathrm{C}$. Data pada Tabel 6 menunjukkan bahwa terjadi penurunan total karoten sesudah interesterifikasi enzimatik menggunakan reaktor batch.

Hasil analisis juga menunjukkan bahwa semakin lama reaksi, maka retensi karoten semakin menurun. Retensi karoten berkisar antara $74,80-81,08 \%$. Penurunan karoten ini diduga karena adanya oksigen dan panas yang mengkatalisa oksidasi karoten dalam minyak selama reaksi. SMP sebelum dan sesudah interesterifikasi enzimatik menggunakan reaktor batch ditunjukkan pada Tabel 7. Hasil uji ragam menunjukkan bahwa SMP antar sampel berbeda nyata. Uji lanjut Duncan terhadap SMP sampel sebelum dan sesudah interesterifikasi enzimatik menunjukkan bahwa antara sampel sebelum dan sesudah interesterifikasi enzimatik berbeda nyata $(p<0,05)$. Perbedaan nyata juga ditunjukkan pada SMP antar sampel setelah interesterifikasi enzimatik. Hal ini menunjukkan bahwa reaksi interesterifikasi enzimatik dengan perbedaan lama waktu 2 jam dapat mengubah nilai SMP.

Tabel 6. Total karoten campuran sebelum dan sesudah interesterifikasi enzimatik (IE) menggunakan reaktor batch

\begin{tabular}{llllll}
\hline \multirow{2}{*}{ Campuran } & & & \multicolumn{2}{c}{ Total Karoten $(\mathrm{ppm})}$, & \multirow{2}{*}{ Retensi } \\
RPO/RPS: & Lama & Kode & \multicolumn{2}{c}{$\mathrm{n=4}$} & Karoten \\
\cline { 3 - 4 } CNO $(\mathrm{b} / \mathrm{b})$ & Reaksi & & Sebelum & Sesudah & $(\%), \mathrm{n}=4$ \\
\hline
\end{tabular}


Versi Online:

http://journal.ipb.ac.id/index.php/jtip

DOI: 10.6066/jtip.2012.23.2.117

Hasil Penelitian

\begin{tabular}{|c|c|c|c|c|c|}
\hline & 2 jam & M772 & $\begin{array}{c}265,01 \pm \\
12,65^{c}\end{array}$ & $\begin{array}{c}212,24 \pm \\
4,96^{\text {ab }}\end{array}$ & 80,09 \\
\hline \multirow[t]{3}{*}{$77,5: 22,5$} & 4 jam & M774 & $\begin{array}{c}265,01 \pm \\
12,65 c\end{array}$ & $\begin{array}{c}200,16 \pm \\
0,18^{\mathrm{a}}\end{array}$ & 75,53 \\
\hline & $6 \mathrm{jam}$ & M776 & $\begin{array}{r}265,01 \pm \\
12,65^{c}\end{array}$ & $\begin{array}{c}198,22 \pm \\
0,14^{\mathrm{a}}\end{array}$ & 74,80 \\
\hline & $2 \mathrm{jam}$ & M822 & $\begin{array}{c}269,02 \pm \\
8,73^{c}\end{array}$ & $\begin{array}{c}218,12 \pm \\
2,69^{\mathrm{b}}\end{array}$ & 81,08 \\
\hline \multirow[t]{2}{*}{$82,5: 17,5$} & 4 jam & M824 & $\begin{array}{c}269,02 \pm \\
8,73^{\circ}\end{array}$ & $\begin{array}{c}209,31 \pm \\
1,84 \text { ab }\end{array}$ & 77,80 \\
\hline & $6 \mathrm{jam}$ & M826 & $\begin{array}{c}269,02 \pm \\
8,73^{c}\end{array}$ & $\begin{array}{r}207,53 \pm \\
1,66^{\text {ab }}\end{array}$ & 77,14 \\
\hline
\end{tabular}

sebelum interesterifikasi enzimatik. Hal ini konsisten dengan hasil penelitian tahap sebelumnya dan sesuai dengan hasil penelitian Goli et al. (2008), Ribeiro et al. (2009), Adhikari et al. (2009), Soares et al. (2009), Mayamol et al. (2009), Sellami et al. (2012), Soares et al. (2012), Khatoon et al. (2012), dan Lee et al. (2008). Perubahan komposisi triasilgliserol akibat interesterifikasi enzimatik menyebabkan perubahan SFC karena setiap triasilgliserol memiliki titik leleh yang berbeda-beda.

Keterangan : Angka yang diikuti huruf yang sama tidak berbeda nyata dengan uji ragam dan uji lanjut Duncan pada taraf uji $5 \%$

Tabel 7. Nilai SMP sebelum dan sesudah interesterifikasi enzimatik (IE) menggunakan reaktor batch dibandingkan dengan SMP margarin komersial dan margarin target (Fattahi-far et al., 2006)

\begin{tabular}{lcc}
\hline \multirow{2}{*}{ Sampel } & \multicolumn{2}{c}{$\operatorname{SMP}\left({ }^{\circ} \mathrm{C}\right)$} \\
\cline { 2 - 3 } M772 & $35,6 \pm 0,5^{\mathrm{e}}$ & $30,8 \pm 0,4^{\mathrm{a}}$ \\
M774 & $35,6 \pm 0,5^{\mathrm{e}}$ & $32,6 \pm 0,2^{\mathrm{b}}$ \\
M776 & $35,6 \pm 0,5^{\mathrm{e}}$ & $34,1 \pm 0,2^{\mathrm{c}}$ \\
M822 & $36,5 \pm 0,4^{\mathrm{f}}$ & $32,0 \pm 0,0^{\mathrm{b}}$ \\
M824 & $36,5 \pm 0,4^{\mathrm{f}}$ & $33,5 \pm 0,0^{\mathrm{c}}$ \\
M826 & $36,5 \pm 0,4^{\mathrm{f}}$ & $34,9 \pm 0,2^{\mathrm{d}}$ \\
Margarin komersial A & & $35,6 \pm 0,2$ \\
Margarin komersial B & & $37,2 \pm 0,0$ \\
Margarin target (Fattahi- & & $33,5 \pm 0,5$ \\
far et al., 2006) & & \\
\hline Keterangan : Angka yang diikuti huruf yang sama tidak berbeda nyata dengan \\
uji ragam dan uji lanjut Duncan pada taraf $5 \%$. M772, M774, dan M776 \\
adalah sampel dengan rasio RPO/RPS:CNO sebesar 77,5:22,5 (b/b) dengan \\
lama reaksi masing-masing 2, 4, dan 6 jam; M822, M824, dan M826 adalah \\
sampel dengan rasio RPO/RPS:CNO sebesar 82,5:17,5 (b/b) dengan lama \\
reaksi masing-masing 2, 4, dan 6 jam
\end{tabular}

SMP meningkat dengan adanya peningkatan komposisi RPS sebagai sumber lemak jenuh bertitik leleh tinggi. Norizzah et al. (2004) menyatakan bahwa peningkatan SMP terkait dengan peningkatan komposisi stearin sawit yang mengandung triasilgliserol bertitik leleh tinggi seperti PPP (tripalmitin) dan POP (palmitat-oleat-palmitat). Interesterifikasi menyebabkan penurunan SMP. Hal ini konsisten dengan hasil penelitian tahap sebelumnya dan sesuai dengan penelitian-penelitian yang telah dilaporkan sebelumnya (Goli et al., 2008; Ribeiro et al., 2009; Soares et al., 2009; Sellami et al., 2012; Soares et al., 2012; Khatoon et al., 2012; dan Lee et al., 2008). Penurunan SMP disebabkan oleh perubahan komposisi asam lemak pada triasilgliserol. SMP hasil interesterifikasi mendekati SMP margarin target tetapi lebih rendah dari SMP margarin komersial. Berdasarkan nilai SMP ini, maka dapat dikatakan bahwa hasil interesterfikasi memiliki potensi penggunaan sebagai bahan baku spreads khususnya margarin.

SFC menunjukkan keberadaan lipid yang berbentuk padat (mengkristal) pada suhu tertentu (Lee et al., 2008). Oleh karena itu SFC berpengaruh pada sifat fisik produk spreads. Hasil analisis SFC sampel sesudah interesterifikasi enzimatik ditunjukkan pada Gambar 5-6. Berdasarkan gambar tersebut terlihat bahwa sampel sesudah interesterifikasi enzimatik cenderung memiliki SFC yang lebih rendah dibandingkan

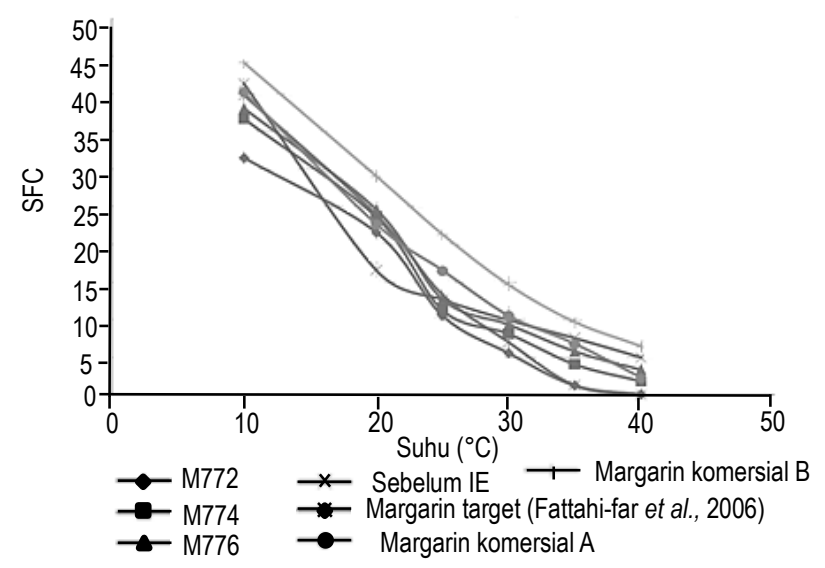

Gambar 5. Profil SFC sampel M772, M774, M776 sebelum dan sesudah interesterifikasi enzimatik (IE) menggunakan reaktor batch yang dibandingkan dengan profil SFC margarin komersial $\mathrm{A}$, margarin komersial $\mathrm{B}$, dan margarin target (Fattahi-far et al., 2006) $(n=4)$

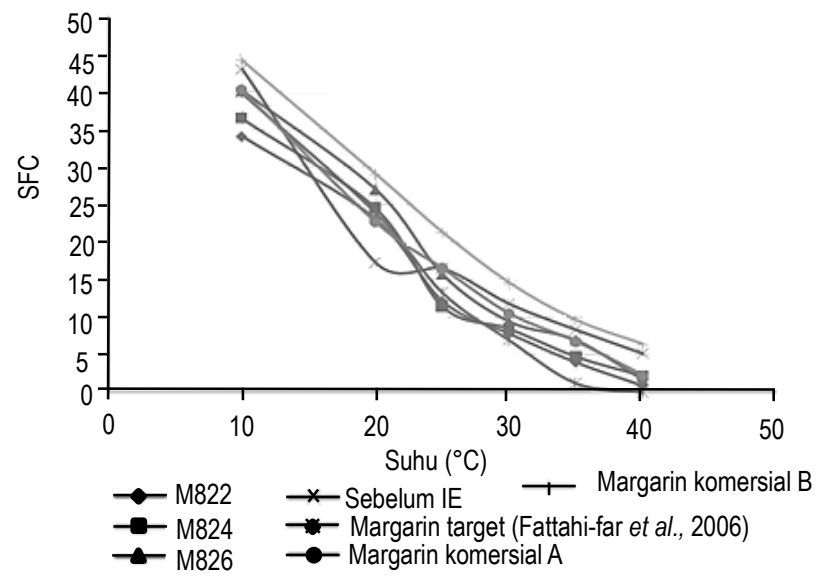

Gambar 6. Profil SFC sampel M822, M824, M826 sebelum dan sesudah interesterifikasi enzimatik (IE) menggunakan reaktor batch yang dibandingkan dengan profil SFC margarin komersial $A$, margarin komersial $B$, dan margarin target (Fattahi-far et al., 2006) $(n=4)$

SFC hasil interesterifikasi mendekati SFC margarin target tetapi lebih rendah dibandingkan SFC margarin komersial. Hal ini mengindikasikan adanya potensi penggunaan hasil interesterifikasi sebagai bahan baku spreads khususnya margarin. 
Versi Online:

http://journal.ipb.ac.id/index.php/jtip

DOI: 10.6066/itip.2012.23.2.117

Hasil Penelitian

J. Teknol. dan Industri Pangan, Vol. XXIII No. 2 Th. 2012

Kadar air dalam suatu produk olahan lemak merupakan salah satu parameter penting karena kadar air sangat berpengaruh pada kadar ALB dalam produk. Kandungan air yang tinggi pada minyak dan produk olahannya dapat mempercepat kerusakan akibat reaksi hidrolisis dan meningkatkan kadar ALB di dalamnya. Hidrolisis adalah pembentukan gliserol dan ALB melalui pemecahan molekul lemak dan penambahan air. Hasil analisis kadar air dan kadar ALB pada sampel sesudah interesterifikasi enzimatik ditunjukkan pada Tabel 8 dan Tabel 9 .

Tabel 8. Kadar air sampel sebelum dan sesudah interesterifikasi enzimatik (IE) menggunakan reaktor batch

\begin{tabular}{ccc}
\hline \multirow{2}{*}{ Sampel } & \multicolumn{2}{c}{ Kadar Air (\%), $\mathrm{n}=4$} \\
\cline { 2 - 3 } & $0,086 \pm 0,000^{\mathrm{a}}$ & Sesudah IE \\
\hline M772 & $0,086 \pm 0,000^{\mathrm{a}}$ & $0,114 \pm 0,004^{\mathrm{c}}$ \\
M774 & $0,086 \pm 0,000^{\mathrm{a}}$ & $0,124 \pm 0,002^{\mathrm{e}}$ \\
M776 & $0,093 \pm 0,002^{\mathrm{b}}$ & $0,112 \pm 0,002^{\mathrm{d}}$ \\
M822 & $0,093 \pm 0,002^{\mathrm{b}}$ & $0,125 \pm 0,002^{\mathrm{e}}$ \\
M824 & $0,093 \pm 0,002^{\mathrm{b}}$ & $0,137 \pm 0,002^{\mathrm{f}}$ \\
\hline
\end{tabular}

Keterangan : Angka yang diikuti huruf yang sama tidak berbeda nyata dengan uji ragam dan uji lanjut Duncan pada taraf 5\%. M772, M774, dan M776 = sampel dengan rasio RPO/RPS:CNO sebesar 77,5:22,5 (b/b) dengan lama reaksi selama masing-masing 2, 4, dan 6 jam; M822, M824, dan M826 = sampel dengan rasio RPO/RPS:CNO sebesar 82,5:17,5 (b/b) dengan lama reaksi masing-masing 2, 4, dan 6 jam

Tabel 9. Kadar asam lemak bebas (ALB) sampel sebelum dan sesudah interesterifikasi enzimatik (IE) menggunakan reaktor batch

\begin{tabular}{ccc}
\hline \multirow{2}{*}{ Sampel } & \multicolumn{2}{c}{$\operatorname{Kadar} \mathrm{ALB}(\%), \mathrm{n}=4$} \\
\cline { 2 - 3 } & Sebelum IE & Sesudah IE \\
\hline M772 & $1,01 \pm 0,01^{\mathrm{a}}$ & $2,94 \pm 0,06^{\mathrm{b}}$ \\
M774 & $1,01 \pm 0,0^{\mathrm{a}}$ & $3,02 \pm 0,04^{\mathrm{bc}}$ \\
M776 & $1,01 \pm 0,01^{\mathrm{a}}$ & $3,16 \pm 0,06^{\mathrm{cd}}$ \\
M822 & $1,24 \pm 0,03^{\mathrm{a}}$ & $3,06 \pm 0,08^{\mathrm{bc}}$ \\
M824 & $1,24 \pm 0,03^{\mathrm{a}}$ & $3,16 \pm 0,01^{\mathrm{cd}}$ \\
M826 & $1,24 \pm 0,03^{\mathrm{a}}$ & $3,25 \pm 0,08^{\mathrm{d}}$ \\
\hline
\end{tabular}

Keterangan : Angka yang diikuti huruf yang sama tidak berbeda nyata dengan uji ragam dan uji lanjut Duncan pada taraf 5\%. M772, M774, dan M776 = sampel dengan rasio RPO/RPS:CNO sebesar 77,5:22,5 (b/b) dengan lama reaksi masing-masing 2, 4, dan 6 jam; M822, M824, dan M826 = sampe dengan rasio RPO/RPS:CNO sebesar 82,5:17,5 (b/b) dengan lama reaks masing-masing 2, 4, dan 6 jam

Berdasarkan hasil uji ragam, kadar air antar sampel berbeda nyata. Uji lanjut Duncan menunjukkan bahwa kadar air sampel sebelum dan sesudah interesterifikasi enzimatik berbeda nyata $(p<0,05)$. Kadar air antar sampel sesudah interesterifikasi enzimatik berbeda nyata. Hal ini menunjukkan bahwa interesterifikasi enzimatik dengan perbedaan lama reaksi 2 jam dapat mengubah kadar air. Tabel 8 menunjukkan bahwa terjadi peningkatan kadar air sesudah interesterifikasi enzimatik. Peningkatan kadar air diduga disebabkan oleh terbentuknya air selama reaksi interesterifikasi akibat esterifikasi yang terjadi setelah hidrolisis. Reaksi interesterifikasi sendiri menghasilkan air.

Hasil uji ragam menunjukkan bahwa kadar ALB antar sampel berbeda nyata. Uji Duncan menunjukkan bahwa kadar ALB sebelum dan sesudah interesterifikasi enzimatik berbeda nyata $(p<0,05)$. Kadar ALB sampel sesudah interesterifikasi enzimatik M776 berbeda nyata dengan M772 dan M774, begitu pula M826 berbeda nyata dengan sampel M822 dan M824. Data pada Tabel 8 dan Tabel 9 menunjukkan bahwa semakin tinggi kadar air pada sampel, maka kadar ALB juga semakin tinggi. Reshma et al. (2008) menyatakan bahwa terbentuknya ALB akibat interesterifikasi enzimatik dapat disebabkan oleh aktivitas air (aw) sistem, komposisi medium, dan biokatalisator yang digunakan. Sesudah interesterifikasi enzimatik, terlihat bahwa terjadi peningkatan kadar ALB.

\section{KESIMPULAN}

Campuran minyak sawit merah (RPO/RPS) dan minyak kelapa dengan perbandingan berat 77,5:22,5 dan 82,5:17,5 dapat dijadikan bahan baku reaksi interesterifikasi enzimatik menggunakan reaktor batch untuk produksi bahan baku spreads. Total karoten, SMP, dan SFC cenderung menurun sesudah interesterifikasi enzimatik. Nilai SMP dan SFC cenderung meningkat dengan bertambahnya lama reaksi. Kadar air dan kadar ALB meningkat sesudah interesterifikasi enzimatik. Hasil interesterifikasi enzimatik memiliki SMP $(30,8-$ $34,9^{\circ} \mathrm{C}$ ) dan SFC yang sudah mendekati SMP dan SFC margarin target. Hal ini menunjukkan bahwa hasil interesterifikasi enzimatik memiliki potensi untuk digunakan sebagai bahan baku spreads khususnya margarin.

\section{UCAPAN TERIMAKASIH}

Penelitian ini didanai oleh Kementerian Pendidikan Nasional melalui Hibah Kompetitif Strategis Nasional 2009.

\section{DAFTAR PUSTAKA}

Adhikari P, Shin JA, Lee JH, Hu JN, Hwang KT, Lee KT. 2009. Enzymatic production of trans-free hard fat stock from fractionated rice bran oil, fully hydrogenated soybean oil, and conjugated linoleic acid. J Food Sci 74: E87-E96. DOI: 10.1111/i.1750-3841.2009.01052.x.

Adhikari P, Shin JA, Lee HL, HU JN, Zhu XM, Akoh CC, Lee KT. 2010. Production of trans-free margarine stock by enzymatic interesterification of rice bran oil, palm stearin and coconut oil. J Sci Food Agric 90: 703-711. DOI: 10.1002/jsfa.3872.

Aini IN, Hasmadi M, Mamot S, Radzuan J. 2005. Palm oil and sunflower oil: effect of blend composition and stirrer types during fractionation on the yield and physicochemical properties of the oleins. J Food Lipids 12: 48-61. DOl: 10.1111/j.1745-4522.2005.00005.x. 
[AOAC] Association of Official Analytical Chemists. 1995. Official Methods of Analysis of The Association of Official Analytical Chemists. AOAC Int., Washington DC.

[AOCS] American Oil Chemistry Society. 1990. Official Methods and Recommended Practices of American Oil Chemistry Society. AOCS Campaign, Illinois.

Budiyanto, Devi S, Zulman E. 2008. Perubahan Kandungan ßKaroten dan kandungan Asam Lemak Bebas Minyak Sawit Merah selama Pemanasan. [Prosiding] Seminar Nasional Sains dan Teknologi-II 2008, Universitas Lampung, Lampung.

Chae MH, Park HK, Kwon KI, Kim JW, Hong SI, Kim Y, Kim BH, Kim IH. 2011. Lipase-catalyzed interesterification in packed bed reactor using 2 different temperatures. J Food Sci 76: C555-C559. DOI: 10.1111/j.1750-3841.2011.02115.x.

Choo Y, Ma A, Barison Y. 1993. Red palm oil: A potential source of dietary carotene. Malaysian Oil Sci Technol 2: 54-55.

Cowan D. 2009. Does the Lipase Source or Oil Composition Influence Enzymatic Interesterification? General Processing the 100th AOCS Annual Meeting \& Expo, Orlando, Florida.

[Ditjenbun] Direktorat Jenderal Perkebunan. 2011. Luas areal dan produksi perkebunan seluruh Indonesia menurut pengusahaan. Ditjebun.deptan.go.id [4 Juni 2011].

Fattahi-far E, Sahari MA, Barzegar M. 2006. Interesterification of tea seed oil and its application in margarine production. J. Am Oil Chem Soc 83: 841-845. DOI: 10.1007/s11746-0065035-9.

Goli SAH, Sahri MM, Kadivar M. 2008. Enzymatic interesterification of structured lipids containing conjugated linoleic acid with palm stearin for possible margarine production. Eur J Lipid Sci Technol 110: 1102-1108. DOI: 10.1002/ejlt. 200800134

Gee PT. 2007. Analytical characteristics of crude and refined palm oil and fractions. Eur. J Lipid Sci Technol 109: 373379. DOI: $10.1002 / e j$ lt.200600264.

Hasrini RF, Sugiyono, Hariyadi P, Andarwulan N. 2009. Interesterifikasi enzimatik dengan lipase pada campuran minyak sawit merah dan minyak kelapa untuk menghasilkan bahan baku spreads kaya ß-karoten. J Agro-based Industry 26: $25-36$.

Hernandez AL, Otero C, Martín EH, Garcia HS, Hill Jr CG. 2007. Interesterification of sesame oil and a fully hydrogenated fat using an immobilized lipase catalyst in both batch and continuous flow processes. Eur J Lipid Sci Technol 109: 1147-1159. DOI: 10.1002/ejlt.200700112.

[IUPAC] International Union of Pure and Applied Chemistry NORM VERSION. 1987. 2. 150 (Ex 2.323) Solid Content Determination in Fats by NMR (Low Resolution Nuclear Magnetic Resonance).

Karabulut I, Turan S, Ergin G. 2004. Effects of chemical interesterification on solid fat content and slip melting point of fat/oil blends. Eur Food Res Technol 218: 224-229. DOl: 10.1007/s00217-003-0847-4.
Khatoon S, Khan MI, Jeyarani T. 2012. Enzymatic interesterification of palm and coconut stearin blends. Int $\mathrm{J}$ Food Sci Technol 47: 2259-2265. DOI: 10.1111/j.13652621.2012.03096.x.

Kim IH, Lee SM, Lee BM, Park HK, Kim JY, Kwon KI, Kim JW, Lee JS, Kim YH. 2008. Interesterification of olive oil with a fully hydrogenated fat in a batch reactor using step changes in temperature. J Agric Food Chem 56: 5942-5946. DOl: 10.1021/jf8007585.

Lea P, Naes T, Rodbotten M. 1997. Analysis of Variance for Sensory Data. John Willey and Sons, Chichester, New York.

Lee JH, Akoh CC, Himmelsbach DS, Lee KT. 2008. Preparation of interesterified plastic fats from fats and oils free of trans fatty acid. J Agric Food Chem 56: 4039-4046. DOl: 10.1021/jf072936y.

Lee JH, Akoh CC, Lee KT. 2008. Physical properties of transfree bakery shortening produced by lipase-catalyzed interesterification. J Am Oil Chem Soc 85: 1-11. DOI: 10.1007/s11746-007-1155-0.

Lida HMDN, Ali ARM. 1998. Physico-chemical characteristics of palm-based oil blends for the production of reduced fat spreads. J Am Oil Chem Soc 75: 1625-1631. DOI: 10.1007/s11746-998-0103-y.

Lida HMDN, Sundram K, Siew WL, Aminah A, Mamot S. 2002. TAG composition and solid fat content of palm oil, sunflower oil, and palm kernel olein belends before and after chemical interesterification. J Am Oil Chem Soc 79: 1137-1144. DOI: 10.1007/s11746-002-0617-0.

Liu Y, Meng Z, Shan L, Jin Q, Wang X. 2010. Preparation of specialty fats from beef tallow and canola oil by chemical interesterification: physico-chemical properties and bread applications of the products. Eur Food Res Technol 230: 457-466. DOI: 10.1007/s00217-009-1188-8.

Mayamol PN, Balachandran C, Samuel T, Sundaresan A, Arumughan C. 2009. Zero trans shortening using rice bran oil, palm oil and palm stearin through interesterification at pilot scale. Int J Food Sci Technol 44: 18-28. DOl: 10.1111/j.1365-2621.2008.01627.x.

Maulina J. 2004. Pembuatan pengganti mentega coklat (CBS) melalui reaksi interesterifikasi antara minyak kelapa, stearin kelapa sawit yang diperkaya omega-3 (n-3) etil ester asam lemak ikan sardencis dengan menggunakan katalis natrium etoksida. J Penelitian Bidang IImu Pertanian 2: 56-72.

Norizzah AR, Chong CL, Cheow CS, Zaliha O. 2004. Effects of chemical interesterification on physicochemical properties of palm stearin and palm kernel olein blends. J Food Chem 86: 229-235. DOI: 10.1016/i.foodchem.2003.09.030.

Osório NM, da Fonseca MMR, Dias SF. 2006. Operational stability of Thermomyces lanuginosa lipase during interesterification of fat in continuous packed bed reactors. Eur J Lipid Sci Technol 108: 545-553. DOl: 10.1002/ej|t.200600029.

[PORIM] Palm Oil Research Institute of Malaysia. 1995. Test Methods For Palm Oil and Palm Oil Products. Palm Oil Research Institute of Malaysia, Kuala Lumpur. 
Versi Online:

http://journal.ipb.ac.id/index.php/jtip

DOI: 10.6066/itip.2012.23.2.117

Pusat Penelitian Kelapa Sawit. 2010. Produksi, ekspor, dan konsumsi minyak sawit Indonesia. http://iopri.org/stat produksi [6 Oktober 2010].

Reshma MV, Saritha SS, Balachandran C, Arumughan C. 2008. Lipase catalyzed interesterification of palm stearin and rice bran oil blends for preparation of zero trans shortening with bioactive phytochemicals. J Bioresource Technol 99: 50115019. DOI: 10.1016/j.biortech.2007.09.009.

Ribeiro APB, Basso RC, Grimaldi R, Gioielli LA, Goncalves LAG. 2009. Effect of chemical interesterification on physicochemical properties and industrial applications of canola oil and fully hydrogenated cottonseed oil blends. J Food Lipids 16: 362-381. DOI: 10.1111/j.17454522.2009.01152.x.

Rossi M, Gianazza M, Alamprese C, Stanga F. 2001. The effect of bleaching and physical refining on color and minor components of palm oil. J Am Oil Chem Soc 78: 1051-1055. DOl: 10.1007/s11746-001-0387-8.

Sellami M, Ghamgui H, Frikha F, Gargouri Y, Miled N. 2012. Enzymatic transesterification of palm stearin and olein blends to produce zero-trans margarine fat. BMC Biotechnol 12: 48. DOI: 10.1186/1472-6750-12-48.

Soares FASDM, da Silva RC, da Silva KCG, Lourenço MB, Soares DF, Gioielli LA. 2009. Effects of chemical interesterification on physicochemical properties of blends of palm stearin and palm olein. Food Res Int 42: 1287-1294. DOI: 10.1016/i.foodres.2009.03.022.

Soares FASDM, da Silva RC, Hazzan M, Capacla IR, Viccola ER, Maruyama JM, Gioielli LA. 2012. Chemical interesterification of blends of palm stearin, coconut oil, and canola oil: physicochemical properties. J Agric Food Chem 60: 1461-1469. DOI: 10.1021/j204111t.

Xu X, Porsgaard T, Zhang H, Nissen JA, Høy CE. 2002. Production of structured lipids in a packed-bed reactor with Thermomyces lanuginosa lipase. J Am Oil Chem Soc 79: 561-565. DOI: 10.1007/s11746-002-0522-6.

Zhang H, Xu X, Mu H, Nilsson J, Nissen JA, Hoy CE. 2000. Lipozyme IM-catalyzed interesterification for the production of margarine fats in a $1 \mathrm{~kg}$ scale stirred tank reactor. Starch/Stärke 52: 221-228. DOI: 10.1002/1521379X(200007)52:6/7<221::AID-STAR221>3.0.CO;2-B.

Zhang $\mathrm{H}, \mathrm{Xu} \mathrm{X}$, Nilsson J, Mu H, Adler-Niessen J, Hoy CE. 2001. Production of margarine fats by enzymatic interesterification with silica-granulated Thermomyces lanuginosa lipase in a large-scale study. J Am Oil Chem Soc 78: 57-64. DOI: 10.1007/s11746-001-0220-4. 